\title{
SOURCE SPECIFIC QUANTIFICATION, CHARACTERISATION AND MANAGEMENT OF SOLID WASTE IN LAPAI, NIGER STATE, NIGERIA \\ ${ }^{*}$ EJARO, S.P. ${ }^{1}$ and JIYA, S.N. ${ }^{2}$ \\ http://dx.doi.org/10.4314/ejesm.v6i5.14
}

\begin{abstract}
Received 6th June 2013; accepted 2nd September 2013
Abstract

The most important aspect of solid waste management is the quantity and characteristics of waste to be managed. Lapai town lacks data on quantity of waste generated and their characteristics for efficient and sustainable waste management. This study is the quantification, characterisation and management of solid waste in Lapai. The study employs the method of source specific quantification and characteristics of the solid waste generated in Lapai because there is no effective landfill and no efficient functional system of waste collection and disposal. 300 questionnaires were administered to selected houses/business premises. At these 300 sampled premises, the solid waste were sorted out, characterized and weighed. The data generated was analysed using descriptive statistics. The study reveals that of the average waste generated per day, food waste has the highest percentage generation of $20 \%$, followed by polythene and plastics with $16 \%$ while wood pieces and saw dust has the least with $2 \%$. For efficient and sustainable solid waste management in Lapai it is recommended that Lapai Local Government Area Council should establish a proper waste management agency in line with the constitutional mandate on refuse disposal enshrined in the fourth schedule of Nigeria constitution. There is the need to reintroduce sanitary inspectors, embark on sustained environmental education and a land fill should be developed and managed properly, just as other methods of waste disposal such as incineration, composting and recycling should be considered.
\end{abstract}

Key words: Solid waste characterisation, waste quantification, waste storage facilities, waste disposal, landfill, sanitary inspectors

\section{Introduction}

Waste generation is inevitable in any human settlement by the nature of human activities. Human activities which directly or indirectly produce waste could be agricultural, commercial, industrial and domestic activities. Generation of waste vary in quantity and types from place to place. It is acknowledged that factors which influence the generation of waste include increased rate of population, industrialization, general economic growth, urbanization, varying consumption patterns and practices of individuals and families (Adedibu, 1983; Bhoyar, et al., 1996; Taboada-Gonzalez, et al., 2010; Bamgboye and Ojolo, 2001; Al-khatib, et al., 2010; Salami, et al., 2011; Okeniyi and Anwan, 2012).

Waste management is a major environmental and health challenge around the world today, and this is more pronounced in developing countries of which Nigeria is one. The agencies responsible for the management of waste are finding it more and more difficult and in spite of their efforts, are unable to render efficient delivery services sustainably. Solid waste requires different methods of handling. The mode of management differs for developed and developing nations, for urban and rural areas, and for residential, industrial and commercial places. In developing countries, solid waste management is faced with challenges, including low collection coverage and irregular collection services, insufficient refuse dumps as well as crude open dump sites, burning without air and water pollution control, the breeding of flies and vermin, and the handling and control of informal waste picking or scavenging activities. These challenges arise because of various factors, which constraints the development of effective solid waste management systems. These constraints according to Pachauri (2000) include technical, financial, institutional, economic, social and external support constraints.

To reduce these constraints, certain measures or approaches are required to develop a working framework for the management of solid waste. This covers the social, economic, technological, political and administrative dimensions. For example, the social dimension involves solid waste minimization, the economic dimension involves waste recycling, and the technological dimension involves waste disposal and the 
political and administrative dimension cuts across all the three issues of minimization, recycling and disposal.

To achieve a sustainable solution to solid waste management, information on its characteristics is necessary. Solid waste is not uniform in material in terms of its constituents, and proper management requires understanding the constituents of solid waste in any locality. Studies on characterization of solid waste have been conducted in different parts of the world (Okeniyi and Anwan, 2012; Salami et al., 2011; Taboada-Gonzalez, et al., 2010; Nabegu, 2010;Al-Khatib, et al., 2010; Oyelola and Babatunde, 2008; Bamgboye and Ojolo,2004; DFID/SLGP Report (805) 2004; BernachePerez, et al., 2001, SAIC, 2000; Oregun DEQ, 1995; CRC,1993; Franklin Associates, Ltd.1988; Adedibu,1983, etc). It is pertinent to observe that results of studies on characterization cannot be generalized towards different regions and seasons because as mentioned earlier, there are many variants such as; cultural traditions, eating habits, consumption patterns, population composition, season of the year and income, that can cause dramatic changes in the composition and generation of waste (Toboada-Gonzalez et.el, 2010).

In Lapai, as in many towns in developing countries, one of the factors that contribute to the poor management of solid waste is the lack of consistent data on the composition and quantity of solid waste being produced. In order to implement an effective solid waste management program, quantitative data on the composition of waste being generated within Lapai, must be obtained. While studies on waste characterization have been conducted for households, markets and cities in some parts of Nigeria (Okeniyi, et al., 2012; Okeniyi and Anwan, 2012; Nabegu, 2010; Oyelola and Babatunde, 2008; Bamgboye and Ojolo, 2004) no study has been conducted in Lapai, a University town.

This study is to quantify and characterise solid waste to provide data to guide the state and local council authorities' environmental protection agency on efficient and sustainable manner of solid waste management.

\section{Study Area}

Lapai is a town and headquarters of a traditional emirate and Local Government Area (LGA), southeastern Niger state, North West Nigeria. Lapai LGA is adjoining Nigeria Federal Capital Territory and the area is roughly coterminous with the Lapai Emirate. Lapai town is on A124 road to the west of the FCT at $9^{\circ} 03^{\prime} 00^{\prime \prime} \mathrm{N} 6^{\circ} 34^{\prime} 00^{\prime \prime} \mathrm{E} / 9^{2} 05000^{\circ} \mathrm{N} 6.56667^{\circ} \mathrm{E}$ (figure1).

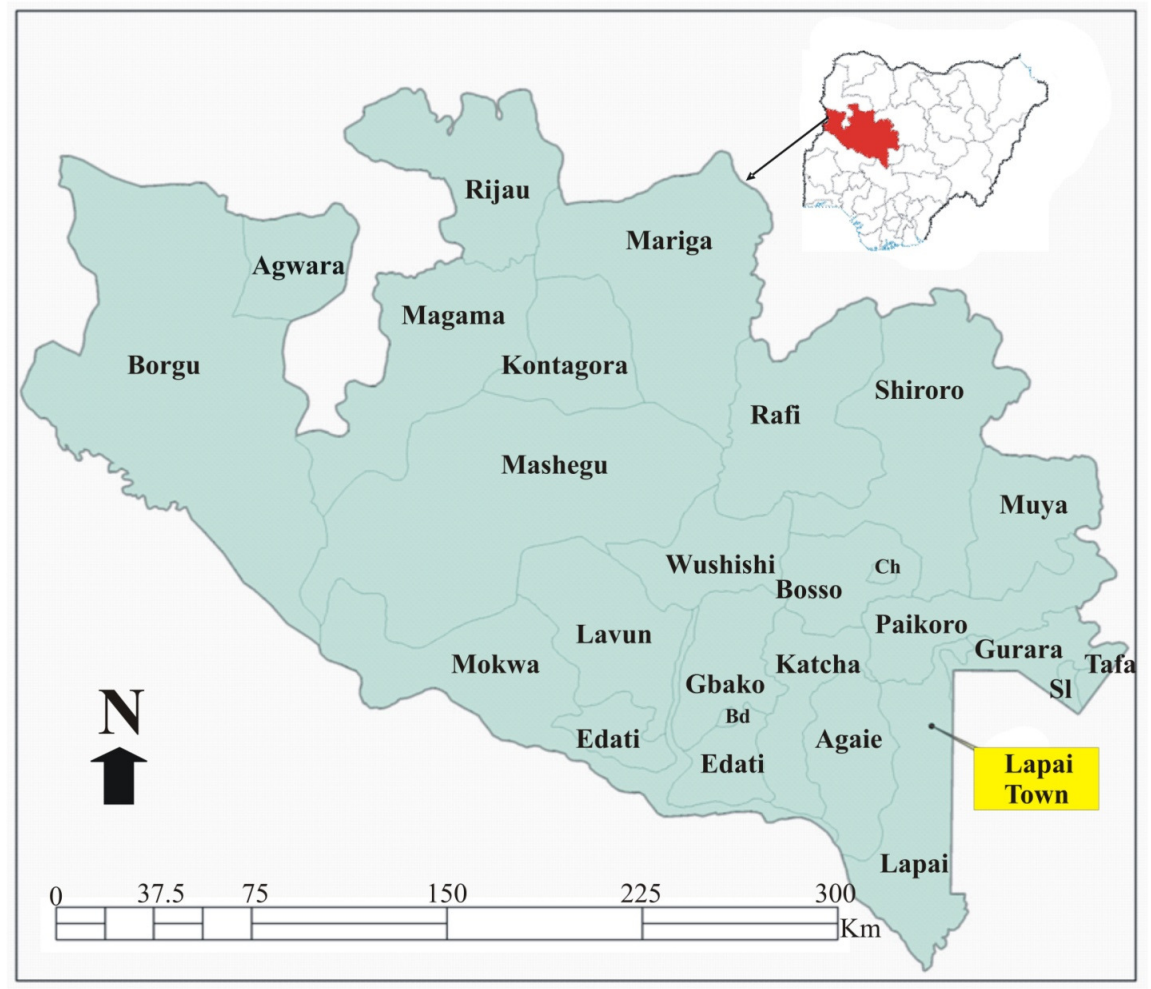

Figure 1 Map of Niger State showing Lapai (the study area) 
Lapai serves as a market centre for sorghum, yams, rice, millet, shea nuts, peanuts (groundnuts), and cotton grown by the area's Gbari and Nupe peoples (Encyclopaedia Britannica, 2013; Wikipedia, 2013). Lapai is a university town where Ibrahim Badamasi Babangida University is located. The population of Lapai in 2006 was 110,127 (NPC, 2006).

Lapai like most Nigerian towns, its internal structure comprises of areas dominated by indigenous people, areas dominated by the nonindigenous people and the commercial area. The indigenous people are found largely in areas/ sections like; Anguwa, Batafu, Badegi, Efu Alhaji, Efu Gwaja, Maraba Gimba,and Takalafiya. The areas where the non-indigenes dominate are the Police barracks and its neighbourhood, Federal Low Cost Housing Estate, Niger State Low Cost Housing Estate, Anambra quarters, Efu Kenchi, Ekpan Danbugi and Ruga Alhaji Joro. The commercial areas are Konata and parts of Badegi.

\section{Materials and Method}

The method employed in this study is the source specific quantification and characterisation described by Gawaikar and Deshpande (2006) and Okeniyi and Anwan (2012). This method is preferred because there are no officially designated landfills and no effective organized waste management system. Individuals and organizations collect their waste and dispose them with no local waste management authority presently involved.

The source specific quantification and characterisation of solid wastes ensures that the study samples are collected directly from the waste generation point or source for better results. Samples collected from the source are sorted out physically into various categories and weighed. The weights are then expressed as a percent of original sample. Gawaikar and Deshpande (2006) note that studies were carried in USA with $100 \mathrm{~kg}$ to $1000 \mathrm{~kg}$ samples and it was found that a $100 \mathrm{~kg}$ sample gave as much accuracy as compared to $1000 \mathrm{~kg}$ sample. When the collection at a point is small, $100 \mathrm{~kg}$ sample cannot be obtained. In such a case, smaller sample could be collected for analysis. Repetitive sampling and analysis would provide a more representative data.

In other to generate the data for this study two approaches were adopted. One was the use of questionnaire and the other was direct field measurement. Questionnaires were prepared and administered to sampled houses/business premises. The sampled households/business premises are called sample points in this study.

At these sample points necessary field measurements were taken also. The town is loosely divided into fifteen areas or sections by the locals. These fifteen areas/sections were adopted and in each area/section. In each area/section, twenty sample points were chosen by systematic sampling technique. It is pertinent to explain that a residential area sample point consists of a house and each household has between 6 and 15 inhabitants. In the traditional or indigenous residential areas, the average household size is 12. The non-indigenes households the average size is 7 . In the case of business premises, the sample point was taken as a shop, a market stall, an eatery/restaurant, a hotel or any commercial enterprise. In the 13 residential areas of the town, 15 questionnaires were administered per area to residential houses and 5 questionnaires for business premises within the residential area. In the remaining 2 mixed areas of Konata and Badegi 10 questionnaires were administered in each area for residential houses and 10 questionnaires for business premises. This amounts to 215 questionnaires for the residential areas and 85 questionnaires for business premises. Thus three hundred questionnaires were administered for the study.

In keeping with Gawaikar and Deshpande (2006) findings that repetitive sampling and analysis would provide a more representative data, measurements were taken at the same source generation sample points for five working days (i.e., Monday - Friday) of the week for eight weeks. The samples were taken in the four weeks of March (which is dry season) and four weeks in May which is rainy season, although not the peak of rainy season. In each sample point the waste was sorted physically into various components and categorized. Each category was weighed. The categories adopted were: bottles/glass, clothes waste, electrical/electronic waste, food waste, leaves and grass, paper waste, polythene/plastics waste, tin/metals, wood waste, and others. All other solid waste not in the categories listed was grouped in the category described as others. A $50 \mathrm{~kg}$ weighing spring balance was used for weighing the samples. Other materials like buckets, pans, hand shovels, and polythene bags were used in the sorting out and measurements of samples. 
The major data solicited through the questionnaire include, the quantity and characterisation of solid waste, waste storage facilities, and method of waste disposal.

\section{Results and discussion}

Quantity and characterisation of solid waste generated

The average daily quantity and characterisation of solid waste generated according to areas or sections in Lapai is presented in table 1. It is pertinent to note that the solid waste generated was measured at the source of generation (i.e. houses/business premises) before disposal. Konata area which is the commercial nerve centre of the town where the motor park is located generates the most waste with $82.5 \mathrm{~kg} /$ day. This is followed by Badegi which is the most populated part of the town and with a fair amount of commercial activities generates $56.0 \mathrm{~kg} / \mathrm{day}$. The area with the least is Ruga Alhaji Joro with $13.0 \mathrm{~kg} /$ day. Ruga Alhaji Joro is a satellite settlement and generates the least waste because it has the least population and the inhabitants are predominantly Fulani herdsmen. In terms of waste characterisation, food waste has the highest percentage generation of $20 \%$ of the average waste generated per day, followed by polythene and plastics with $16 \%$ while wood pieces and saw dust has the least with $2 \%$ (figure 2 ).

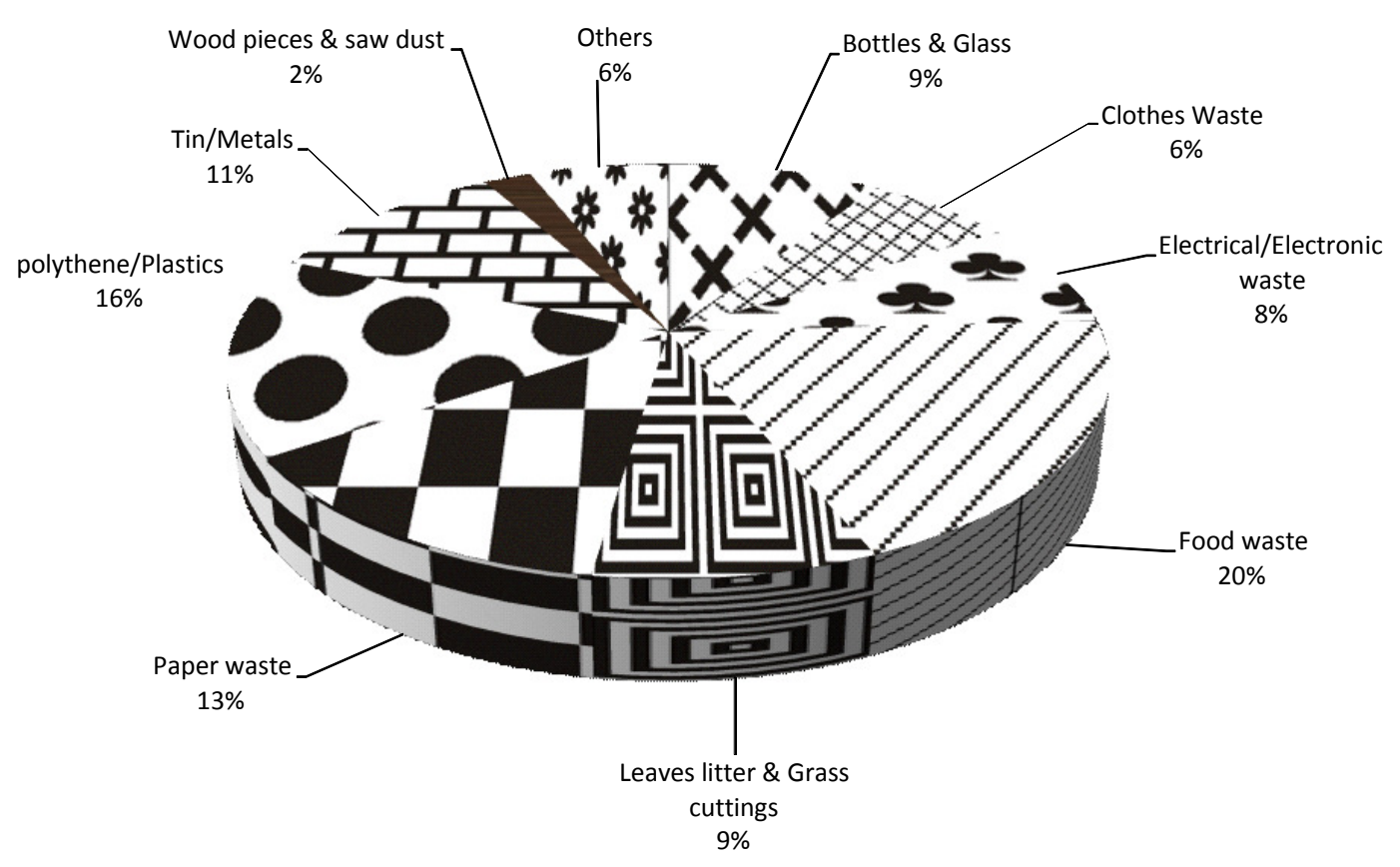

Figure 2 Comparative composition in percentages, of characterized solid waste components

\section{Waste Storage}

The waste storage facilities used by the people in Lapai are presented in table 2, according to different areas or sections of the town in percentages. The facilities are provided by the people themselves. It is depressing to note that a sizeable percentage of the people are still using rice and cement sacks to store waste.
The overall average percentage waste storage facilities for Lapai is presented in figure 3 . The waste storage facility which is most used by the people is waste baskets/buckets with $27 \%$ and the least is the use of cartons with $3 \%$.Other storage facilities which constitute $23 \%$ of the category described as others include earthenware, cane baskets, used paint containers and any other container. 


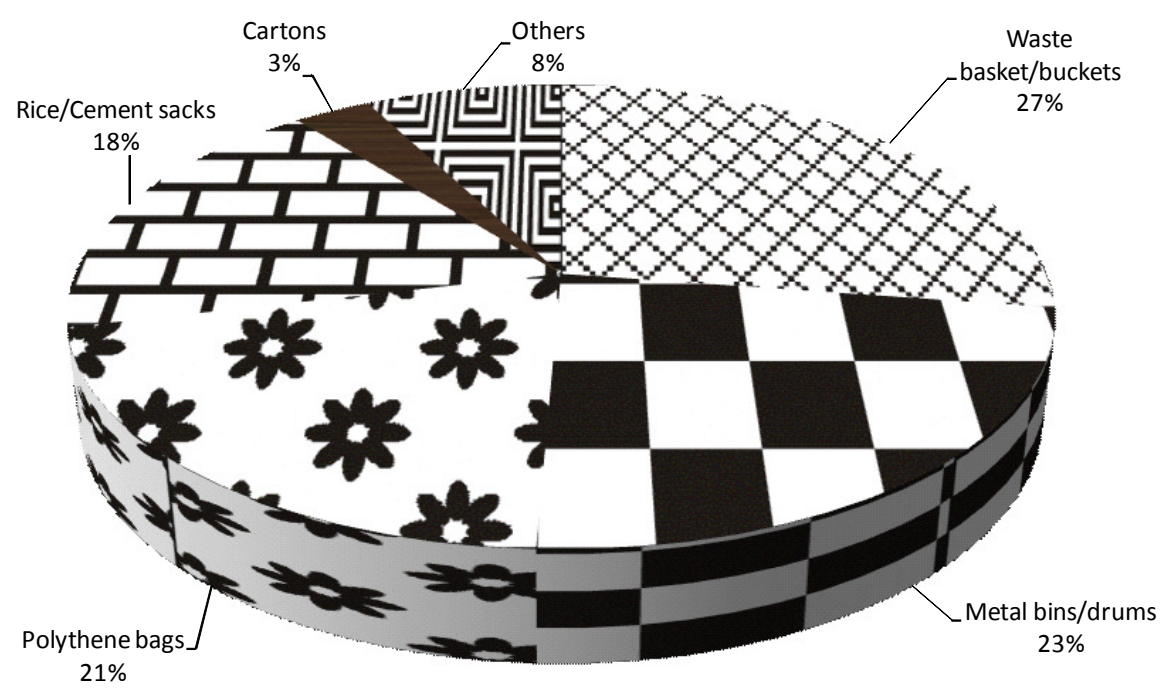

Figure 3 Waste Storage Facilities

\section{Waste Disposal}

The common methods of waste disposal in Lapai are burning of waste, dumping waste on street corners, dumping waste in gutter, burying waste, dumping waste in unapproved dump sites (especially throwing waste in nearby open spaces and bush) and dumping on dump sites. Table 3 shows the methods of waste disposal in percentages according to areas/sections in Lapai. It is alarming that in some areas the major method of waste disposal is dumping waste in unapproved dump sites such as throwing waste in nearby open space or bushes around. At Efu Gwaja and Efu kenchi 50\% of the respondents throw waste in nearby open spaces. Areas at the fringes of Lapai such as Maraba Gimba, Ruga Alhaji Joro and Takalafiya throw their waste into the surrounding bushes and open spaces, which accounts for the high values of $80 \%, 70 \%$ and $75 \%$ respectively. Respondents in Konata (which is the major commercial area of the town) dump their waste at an approved dump site between Simarite petrol station and Akuvera hotel beside river Ndakotsu. Imagine the health hazard posed by that dump site to the people downstream.

The overall average percentage waste disposal methods for Lapai is presented in figure 4. $40 \%$ of the respondents throw their waste in unapproved dump sites, especially nearby open spaces, nearby bushes and uncompleted building. $21 \%$ of the respondents burn their waste. The environmental consequences of burning waste and throwing waste in open spaces are documented in literature. Apart from the offensive odour and air pollution the respondents complain about, they don't appreciate the other health hazards this pose.
It is pertinent to mention that a monthly environmental sanitation exercise was undertaken on the last Saturday of every month and was observed seriously especially between 2003 and 2010. During that period, Niger State environmental sanitation agency would bring refuse trucks to clear the town of all waste. The Lapai Local Government Area had a functional Sanitation Unit in its Primary Health Care Services, which supervised sanitation activities in Lapai and was the liaison with the state environmental sanitation agency at the state capital, Minna. The Sanitation Unit had an office but today its activities are comatose and lack office accomodation. This speaks volume of the kind of dysfunctional waste management system.

Another issue worthy of mention is the location of approved dump sites. There are three dump sites in the town designated by the local government area sanitation authority. These dump sites are located at (i) Fenin Bahra, at the back of Galadima Primary School (ii) Mazugata, water board junction and (iii) Between Simarite petrol station and Akuvera hotel. These dump sites were selected when the town was small but the town has grown and expanded such that these dump sites are now within the town and are now an environmental nuisance and health risk.

A typical example is the location of the dump site between Simarite petrol station and Akuvera hotel which is beside NdaKotsu stream. That location is a health risk to the people downstream. These dump sites were meant to be transit points for waste to be dumped temporarily and then evacuated to more permanent land fill. 


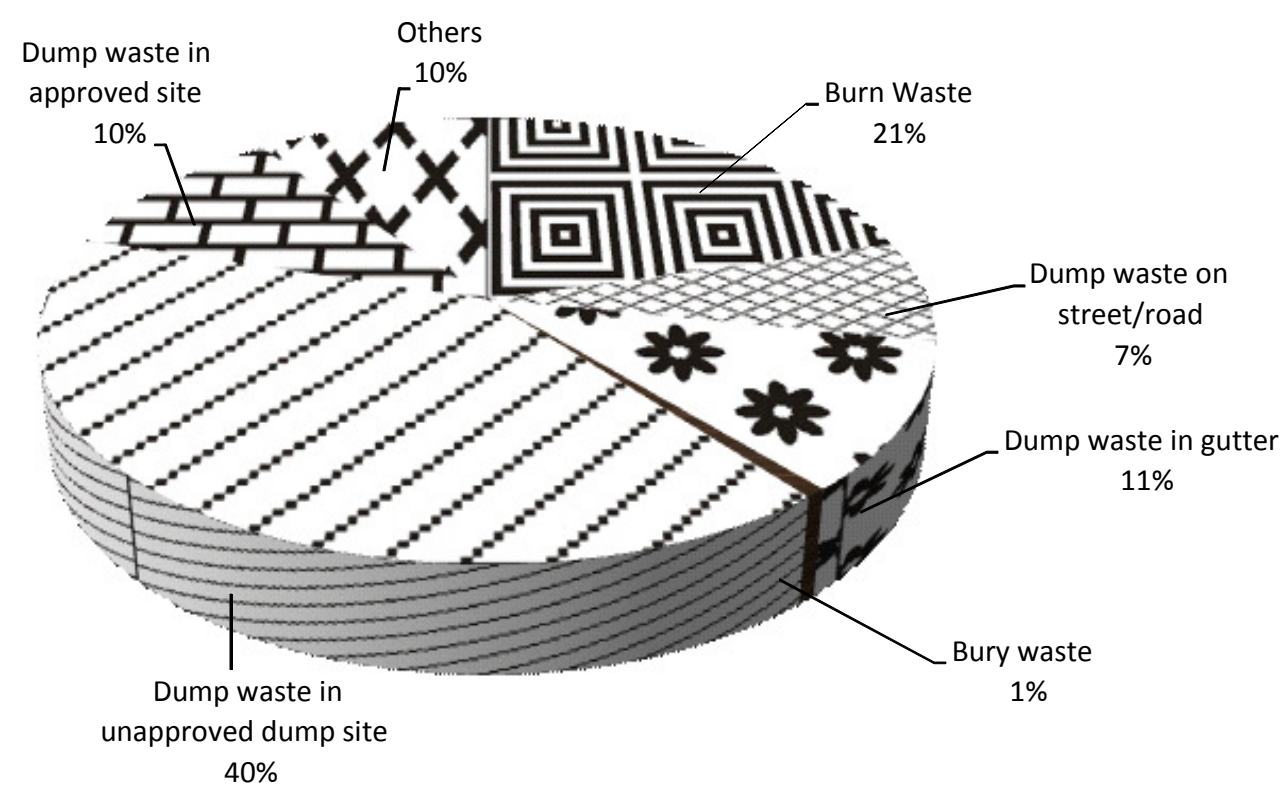

Figure 4 Waste Disposal Methods

The land fill site has not been developed. What exist is open space in the bush far off Lapai town where waste that used to evacuated from these dump sites were dumped.

\section{Conclusion and Recommendations}

Source specific quantification and characterisation of solid waste in Lapai has been carried out in this study. Solid waste management is an environmental and health challenge in Lapai. There is a dysfunctional local government sanitation agency responsible for the management of waste. This sanitation unit is struggling for its survival and relevance. The state sanitation agency, Niger State Environmental protection Board, is finding it more and more difficult and in spite of its efforts, is unable to render efficient delivery services sustainably outside the state capital. The people in Lapai are left on their own to find ways and means of managing the waste they generate. Consequently, the people resort to throwing waste in open spaces, uncompleted buildings, nearby bushes, and other environmentally unsuitable dump sites and even on street corners and gutters. This obviously is not a proper and sustainable manner of solid waste management in Lapai especially with its new status as a university town attracting increasing population and rapid urbanization. Though the environmental sanitation situation is not alarming yet, however, it's heading towards that deplorable state. Relevant agencies should not wait till that deplorable state before measures are taken. It is imperative to abide by the maxim which states that a stitch in time saves nine.

The following measures are recommended for efficient and sustainable waste management system in Lapai:

The local authority, which is Lapai Local Government Area Council, should establish a proper waste management agency for efficient functional system of waste collection and disposal. After all, the Nigeria constitution in the fourth schedule list the functions of a local government council to include "provision and maintenance of public conveniences, sewage and refuse disposal". Due to the paucity of funds at the local government, the state government should assist them. Such assistance should be in terms of provision of equipment and machinery for waste collection and disposal, provision and development of human capacity for modern waste management system.

There is the need to reintroduce sanitary inspectors who monitored environmental cleanliness in the districts in the colonial administration and immediately after independence. These sanitary inspectors should be employed as part of the staff for the local government waste management agency to supervise waste management and maintained environmental cleanliness. 
Environmental education of people in Lapai through public enlightenment and awareness in the media, schools, churches, mosques, community associations, traders and transporters unions, and use of traditional rulers.

\section{References}

Adedibu, A.A. (1983), Solid Waste Characterisation and Management in Ilorin".UNITP 3(1), 33-175

Al-Khatib,I. A.,Monou, M., Abdul S. F. Abu Zahra, Hafez Q. Shaheen, DespoKassinos, (2010), "Solid waste characterization, quantification and management practices in developing countries. A case study: Nablus district - Palestine" Journal of Environmental Management, 91, 1131-1138

Bamgboye, A.I. and Ojolo, S.J. (2004), Characterisation of Municipal solid wastes being generated in Lagos State, Nigeria. LAUTECH Journal of Engineering Technology, 2:36-38

Bernache-perez, G., Sanchez-colon,S., Garmendia, A.M., Davila-Villarreal,A. and Sanchez-Salazar, M.E (2001) Solid waste characterization study in Guadalajara Metropolitan Zone. Mexico. Waste Management Research, 19, 413-424

Bhoyar, R.V.,Titus, S.K., Bhide, A.D.and Khanna, P (1996), 'Municipal and Industrial Solid Waste Management in India'. Journal of Indian Association of Environmental Management, 23, 53-64.

CRC 1.2 National Waste Database National Solid Waste Classification System Version 6 (1993), Background to Draft Solid Waste Classification System for the Commonwealth EPA

http://awd.csiro.au/awdwebsite2003/Awd\%20pu bn\%20PDFiles/classn4.pdf

DFID and SLGP Consultants Report (2004), “ Estimates of Waste Generation Volumes and Income potential in Abuja". DFID CNTR 000512 A and SLGP Consultants report No. 805 Encyclopaedia Britannica (2013) Lapai, Nigeria. http://www.britannica.com/EBchecked/topic/330 277/Lapai

Gawaikar, V. and Deshpande, V.P. (2006), Source Specific Quantification and Characterization of Municipal Solid Waste - a Review. IE(I) Journal-ENVol 86, March 2006 Franklin Associates, Ltd. (1988), Characterization of Municipal Solid Waste in the United States, 1960 to 2000 (Update 1988). U.S.
The undeveloped land fill should be developed and managed properly, just as other methods of waste disposal such as incineration, composting and recycling should be considered.

Environmental Protection Agency. March 30, 1988.

Nabegu,A. B. (2010)An analysis of municipal solid waste in Kano metropolis, Nigeria. Journal of human Ecology, 31, 111-119

National Population Commission (NPC)(2006)

Facts and Figures 2006 Census.

Retrieved at http//www.population.gov.ng

Okeniyi, J. O. and Anwan, E. U. (2012), "Solid Wastes Generation in Covenant University, Ota, Nigeria: Characterisation and Implication for Sustainable Waste Management" J. Mater. Environ. Sci. 3(2),419-424. http://www.jmaterenvironsci.com/

Okeniyi, J. O., Anwan, E.U. and Okeniyi, E.T. (2012), "Waste Characterisation and Recoverable Energy Potential Using Waste Generated in a Model Community in Nigeria". Journal of Environmental Science and Technology, 5(4), 232-240

Oregun DEQ (1995), 'Oregon Solid Waste Characterization and Composition'.

http://www.deq.state.or.us/wmc/solwaste/wcrep/ wcrep93.html 1994-1995

Oyelola, O. T. and Babatunde, A.I (2008), Characterization of domestic and market solid wastes at source in Lagos metropolis, Lagos, Nigeria. African Journal of Environmental Science and Technology, 3, 430-437

Pachauri, R.K. (2000), "Why Waste the Waste". The Indian Express. http;//www.teriin.org/index.htm

Salami L., Susu A.A., Patinvoh R.J.and Olafadehan O.A. (2011), "Characterisation study of solid wastes: a case of Lagos State". International Journal of Applied Science and Technology, 1:3

Science Applications International Corporation (SAIC) (2000), "Characterization of New York City's Solid Waste Streams" prepared for New York City Department of Sanitation, Bureau of Waste prevention, Reuse and Recycling.

http://www.nyc.gov/html/dos/pdf/wprr/wprro6.pdf,

Taboada-Gonzalez, P., Armijo-de-Vega C., AguillarVirgen, Q., and Ojeda-Benitez (2010), "Household Solid Waste Characterisation and management in Rural Communities". The Open Waste Management Journal, 3, 167-173.

Wikipedia (2013), Lapai, Nigeia. http://en.wikipedia.org/wiki/Lapai 
Table 1 Average daily quantity and characterisation of solid waste generated in Lapai

\begin{tabular}{|c|c|c|c|c|c|c|c|c|c|c|c|c|}
\hline S/No & $\begin{array}{l}\text { Area/section } \\
\text { of Lapai }\end{array}$ & $\begin{array}{l}\text { Bottles/ } \\
\text { Glass } \\
\text { (kg/day) }\end{array}$ & $\begin{array}{l}\text { Clothes } \\
\text { Waste } \\
\text { (kg/day) }\end{array}$ & $\begin{array}{l}\text { Electrical/ } \\
\text { Electronic } \\
\text { Waste } \\
\text { (kg/day) }\end{array}$ & $\begin{array}{l}\text { Food } \\
\text { Waste } \\
\text { (kg/day) }\end{array}$ & $\begin{array}{l}\text { Leaves\& } \\
\text { Grass } \\
\text { Cuttings } \\
\text { (kg/day) }\end{array}$ & $\begin{array}{l}\text { Paper } \\
\text { Waste } \\
\text { (kg/day) }\end{array}$ & $\begin{array}{l}\text { Polythene/ } \\
\text { Plastics } \\
\text { (kg/day) }\end{array}$ & $\begin{array}{l}\text { Tin/ } \\
\text { Metals } \\
\text { (kg/day) }\end{array}$ & $\begin{array}{l}\text { Wood } \\
\text { pieces/ } \\
\text { Saw dust } \\
\text { (kg/day) }\end{array}$ & $\begin{array}{l}\text { Others } \\
\text { (kg/day) }\end{array}$ & Total \\
\hline 1 & Anambra Qtrs & 1.5 & 1.0 & 2.0 & 2.0 & 3.0 & 2.0 & 2.5 & 1.5 & 0 & 3.0 & 18.5 \\
\hline 2 & Anguwa & 1.5 & 1.0 & 0 & 3.0 & 4.0 & 0 & 4.5 & 1.0 & 0 & 4.0 & 19.0 \\
\hline 3 & Batafu & 3.0 & 2.5 & 4.0 & 6.5 & 3.0 & 4.0 & 3.0 & 3.5 & 1.0 & 0 & 30.5 \\
\hline 4 & Badegi & 4.5 & 5.5 & 3.5 & 10.5 & 4.5 & 8.5 & 6.5 & 6.0 & 4.5 & 2.0 & 56.0 \\
\hline 5 & EfuAlhaji & 2.5 & 1.5 & 2.5 & 4.0 & 2.0 & 2.5 & 4.5 & 6.0 & 0 & 3.0 & 28.5 \\
\hline 6 & EfuGwaja & 3.5 & 4.0 & 3.5 & 7.5 & 2.5 & 1.5 & 3.5 & 5.0 & 0 & 3.0 & 34.0 \\
\hline 8 & Ekpan Danbugi & 1.5 & 2.0 & 1.5 & 3.0 & 2.5 & 6.5 & 6.0 & 4.0 & 2.0 & 0 & 29.0 \\
\hline 9 & $\begin{array}{l}\text { Federal Low Cost } \\
\text { Housing Estate }\end{array}$ & 3.0 & 3.0 & 4.5 & 14.5 & 3.0 & 8.0 & 6.5 & 4.0 & 0 & 3.0 & 49.5 \\
\hline 10 & Konata & 10.5 & 6.0 & 7.5 & 25.5 & 3.5 & 10.5 & 12.0 & 3.0 & 0 & 4.0 & 82.5 \\
\hline 11 & MarabaGimba & 1.0 & 0 & 0 & 1.0 & 4.0 & 2.0 & 3.0 & 2.5 & 0 & 1.0 & 14.5 \\
\hline 12 & Police barracks & 6.5 & 2.5 & 6.0 & 6.0 & 2.0 & 8.0 & 10.5 & 4.5 & 0 & 2.0 & 48.0 \\
\hline 13 & RugaAlhajiJoro & 1.0 & 0 & 0 & 2.5 & 0 & 1.5 & 2.5 & 3.5 & 2.0 & 0 & 13.0 \\
\hline 14 & $\begin{array}{l}\text { State Low cost } \\
\text { Housing Estate }\end{array}$ & 4.5 & 2.0 & 5.0 & 8.5 & 4.5 & 7.0 & 7.5 & 6.0 & 0 & 5.0 & 50.0 \\
\hline
\end{tabular}

Table 2 Waste storage facilities (in percentages) in the areas/sections of Lapai

\begin{tabular}{|c|c|c|c|c|c|c|c|c|}
\hline S/No & Area/section of Lapai & $\begin{array}{l}\text { Waste } \\
\text { baskets/buckets }\end{array}$ & $\begin{array}{l}\text { Metal } \\
\text { bins/drums }\end{array}$ & Polythene bags & $\begin{array}{l}\text { Rice/cement } \\
\text { sacks }\end{array}$ & Cartons & Others & Total \\
\hline 1 & AnambraQtrs & 15 & 25 & 45 & 10 & 0 & 5 & 100 \\
\hline 2 & Anguwa & 35 & 20 & 20 & 15 & 5 & 5 & 100 \\
\hline 3 & Batafu & 15 & 30 & 20 & 30 & 0 & 5 & 100 \\
\hline 4 & Badegi & 35 & 15 & 10 & 30 & 0 & 5 & 100 \\
\hline 5 & EfuAlhaji & 40 & 20 & 10 & 20 & 5 & 5 & 100 \\
\hline 6 & EfuGwaja & 30 & 30 & 10 & 20 & 0 & 10 & 100 \\
\hline 7 & Efukenchi & 20 & 10 & 25 & 25 & 10 & 10 & 100 \\
\hline 8 & EkpanDanbugi & 35 & 15 & 25 & 10 & 5 & 10 & 100 \\
\hline 9 & Federal Low Cost Housing Estate & 55 & 15 & 30 & 0 & 0 & 0 & 100 \\
\hline 10 & Konata & 30 & 25 & 25 & 10 & 5 & 5 & 100 \\
\hline 11 & MarabaGimba & 15 & 35 & 10 & 30 & 5 & 5 & 100 \\
\hline 12 & Police Barracks & 25 & 40 & 25 & 10 & 0 & 0 & 100 \\
\hline 13 & RugaAlhajiJoro & 10 & 35 & 10 & 20 & 5 & 20 & 100 \\
\hline 14 & State Low Cost Housing Estate & 35 & 15 & 25 & 10 & 5 & 10 & 100 \\
\hline 15 & Takalafiya & 15 & 20 & 20 & 30 & 0 & 15 & 100 \\
\hline
\end{tabular}


Table 3 Waste disposal methods (in percentages) in areas/sections in Lapai

\begin{tabular}{|c|c|c|c|c|c|c|c|c|c|}
\hline $\mathrm{S} / \mathrm{No}$ & $\begin{array}{l}\text { Area/section of } \\
\text { Lapai }\end{array}$ & Burn Waste & $\begin{array}{l}\text { Dump } \\
\text { Waste on } \\
\text { street/ } \\
\text { roadside }\end{array}$ & $\begin{array}{l}\text { Dump } \\
\text { waste } \\
\text { in } \\
\text { gutter }\end{array}$ & $\begin{array}{c}\text { Bury } \\
\text { Waste }\end{array}$ & $\begin{array}{l}\text { Dump waste in } \\
\text { unapproved dump site } \\
\text { (eg open spaces/bushes }\end{array}$ & $\begin{array}{l}\text { Dump waste in } \\
\text { approved } \\
\text { dump site }\end{array}$ & Others & Total \\
\hline 1 & AnambraQtrs & 15 & 10 & 25 & 0 & 30 & 15 & 5 & 100 \\
\hline 2 & Anguwa & 30 & 15 & 10 & 0 & 30 & 5 & 10 & 100 \\
\hline 3 & Batafu & 20 & 10 & 10 & 0 & 35 & 10 & 15 & 100 \\
\hline 4 & Badegi & 5 & 20 & 20 & 0 & 45 & 0 & 10 & 100 \\
\hline 5 & Efu Alhaji & 25 & 15 & 20 & 0 & 10 & 25 & 5 & 100 \\
\hline 6 & Efu Gwaja & 10 & 5 & 25 & 0 & 50 & 0 & 10 & 100 \\
\hline 7 & Efu kenchi & 20 & 10 & 10 & 0 & 50 & 0 & 10 & 100 \\
\hline 8 & Ekpan Danbugi & 25 & 5 & 10 & 5 & 35 & 15 & 5 & 100 \\
\hline 9 & $\begin{array}{l}\text { Eaderal Low Cost } \\
\text { Housing Estate }\end{array}$ & 25 & 5 & 5 & 0 & 20 & 30 & 15 & 100 \\
\hline 10 & Konata & 30 & 0 & 5 & 0 & 10 & 35 & 20 & 100 \\
\hline 11 & Maraba Gimba & 15 & 0 & 0 & 0 & 80 & 0 & 15 & 100 \\
\hline 12 & Police Barracks & 20 & 10 & 15 & 0 & 35 & 5 & 15 & 100 \\
\hline 13 & Ruga Alhaji Joro & 25 & 0 & 0 & 0 & 70 & 0 & 5 & 100 \\
\hline 14 & $\begin{array}{l}\text { State Low Cost } \\
\text { Housing Estate }\end{array}$ & 30 & 5 & 5 & 0 & 30 & 15 & 15 & 100 \\
\hline 15 & Takalafiya & 15 & 0 & 0 & 5 & 75 & 0 & 5 & 100 \\
\hline
\end{tabular}

